\title{
Communis error facit ius in language and in linguistics
}

\section{[Communis error facit ius v jazyku a v jazykovede]}

\author{
Mojmir Malovecky
}

\section{DOI: 10.18355/XL.2016.09.04.25-29}

\begin{abstract}
Anotácia
Štúdia je venovaná všeobecnolingvistickým argumentom previazanosti reči v širšom zmysle ako psychofyzickej schopnosti človeka a vlastností jazykového systému. To je východiskom uvažovania o vzt’ahu medzi normou a úzom v slovenskej a francúzskej lingvistickej tradícii smerom ku kodifikácii jazykovej normy. Osobitná pozornost' je sústredená na uplatnitel'nost' právneho princípu communis error facit ius v jazykovede z pohl'adu dopadov jeho aplikovania pri návrhoch na inováciu jazykovej normy.
\end{abstract}

Kl’účové slová: norma, úzus, kodifikácia, jazykové spoločenstvo, všeobecná lingvistika

Používatelia jazyka sú v moderných časoch povinnej školskej dochádzky systematicky konfrontovaní $\mathrm{s}$ aplikáciou lingvistických teórií vo vyučovaní materinského alebo cudzieho jazyka. Neskôr po opustení školského prostredia sú vzhl'adom na všeobecne prijímanú predstavu o existencii kultivovanej normy jazyka a jej použití v rôznych životných situáciách, pred otázkou, či je kultivovaná norma in res a dá sa $\mathrm{z}$ perspektívy používatel'a odvodit'. odobne ako súvislosti v matematike alebo fyzike. Má v jazyku miesto také uvažovanie o modelovaní, kde sú princípy dané predvídatel'nou sústavou zákonitostí alebo ide o arbitrárnost' resp. konvencionálnost' a v jazyku prevláda symbolický charakter javov, preto nemožno hovorit' pozitívne o systémovosti na úrovni predikability, ako je tomu v spomínaných prírodných vedách. Napríklad, ak v matematike $\mathrm{v}$ rovnici je daná presupozícia súčtu $\mathrm{x}+\mathrm{x}$ alebo $\mathrm{x}+\mathrm{y}$, pretože výsledok je vopred daný tým, čo konštituuje v konkrétnom prípade premenné $\mathrm{x}$ alebo $\mathrm{y}$. Teda $\mathrm{v}$ prípade matematiky a ani napr. fyziky alebo chémie, nemožno mysliet' prírodný zákon ako konvenciu. Výsledok príkladu nemožno určit' dohodou, ten objektívne plynie $\mathrm{z}$ reálneho počtu počítatel'ných položiek, ktoré sú overitel'né $\mathrm{v}$ mimojazykovej skutočnosti. Malé diet’a môže formulovat' jazykovú výpoved', že jeho pät' prstov na jednej ruke plus pät' prstov na druhej ruke je spolu štyridsat' prstov, láskavo mu je však možné mimojazykovo fakticky na jeho rúčkach dokázat', že sa hlboko mýli. Na neodškriepitel'né pravdy a vedeckú podstatu tvrdých vied, si l’udstvo i napriek omylom vedcov, v priebehu vývoja vedy za uplynulé storočie od silného obdobia pozitivizmu až podnes, postupne privyklo. Ako je to však v jazyku a následne nevyhnutne $\mathrm{v}$ jazykovede? Tá, pred a dokonca i počas najväčšieho rozmachu pozitivizmu ako hnacieho motora vied, oscilovala medzi zaradením medzi prírodné alebo humanitné vedy. Pre jej zaradenie medzi humanitné vedy nakoniec okrem iných argumentov t’ažiskovo zavážil omyl a pád argumentov o hláskových zmenách ako prírodnom zákone $\mathrm{v}$ rámci pozitivistického mladogramatického smeru $\mathrm{v}$ jazykovede. Objavy rodiacej sa jazykovej geografie na prelome devätnásteho a dvadsiateho storočia, totiž sekundované limitmi dobového poznania o jazyku nedokázali dat' iné argumenty. Napriek jej humanitnému charakteru mnoho javov a odvetví jazykovedy využíva poznatky a princípy tvrdých vied (napríklad experimentálna fonetika). V 20. storočí uvažovanie o jazykovede ako humanitnej vede azda málo zdôrazňovalo, že už Ferdinand de Saussure (2007) poukázaním na jazyk - langue odkazoval tesne po 
mladogramatikoch na klúčovost' systémovosti, avšak prezieravo nevyhnutne $\mathrm{v}$ spojitosti s langage - rečou v univerzálnom zmysle (takto pojem osvetl'ujú napríklad Ondruš - Sabol: 1984), ktorá ako psychofyzická schopnost' daná len človeku má biologickú podstatu. Prečo vyzdvihujeme biologickost? Pretože bez funkčnej biológie niet schopnosti reči. Nemyslíme len schopnost' reči v zmysle artikulačných orgánov, ale hlavne $\mathrm{v}$ naviazanosti na funkčnost' mozgu, tam prebiehajúcich biochemických funkčných procesov, ktorých len následkom sú kognitívne schopnosti používatel'a jazyka. Teda je isté, že fungovanie jazyka, ako spoločenského fenoménu, je previazané s biologickou funkčnost'ou. Dnešný človek nespochybňuje a taktiež v dejinách sa asi málo spochybňoval fakt, že podstata biologických procesov je viazaná napríklad na fyzikálne a chemické vlastnosti. Napríklad hodnota $\mathrm{pH}$ musí byt' v presných rozmedziach $\mathrm{v}$ orgánoch i na epiteloch. Obdobne je možné vzhl'adom na naše poznanie existencie jazykových univerzálií, ktoré sú vlastne istým vyjadrením limitov a možností systémových vlastností jazyka na základe daností reči (langage), ktorá obsahuje biologickú podstatu predpokladat', že jazyk, v sebe obsahuje objavitel'né princípy a zákonitosti, ktoré prevrstvujú jeho konvenčné vlastnosti. Bližšie k pochopeniu problematiky možno dospiet' poznávaním výsledkov výskumov Lud'ka Hřebíčka (2002), kde najnovšia matematická lingvistika poukazuje na systémové vlastnosti jazyka na doteraz nepoznanej úrovni. Ide vlastne o novú sadu argumentov, ktorá poodkrývava princípy fungovania systému jazyka smerom k tendenciám $\mathrm{k}$ ich vnútornej dynamickej rovnováhe (Dolník: 2013), ktorá sa považuje za fakt . A tu sa už približujeme k sporom a argumentom o tvár jazykovej normy, či dokonca kodifikácie. Akoby homeostatická vlastnost' jazykového systému a zároveň jeho entropia hovorili za argument, že normou môže byt' čokol'vek, lebo systém to takpovediac znesie, teda dokáže vyvážit' inými vlastnost’ami. To je pravda, ale o jazykovom systéme podl'a nášho názoru nie celá. Je to len jedno z hl'adísk, že systém je takto vnútorne chránený pred destabilizáciou a zánikom a $\mathrm{s}$ modifikáciou sa vyrovná. Tento argument však neodpovedá na otázku ako sa potom prejavuje systémovost' a podstata objektívnej väzby na biologickú podstatu schopnosti jazyka u človeka. Určite systémovost', ktorú poodhal'uje Luděk Hřebíček (2002) bude smerovat' $\mathrm{k}$ odhaleniu systematickosti medzi segmentovaním výpovede človekom a uspôsobením procesov myslenia, ktoré majú aj biologický funkčný podklad. Väzba jazykového systému s biologickými danost’ami l'udského tela je teda nevyhnutná, preto sa zrkadlí ako súčast' komunikácie a jej segmentácie. To však ešte neznamená, že tým je dokázaná schopnost' človeka odhalit' zákonitosti v jazyku. Ich deskripcia môže byt' len jednoduchou interpretačnou fikciou, konštrukciou teoretikov, ktorá zhodou okolností celkom pasuje. Sme však presvedčení, že pokial' berieme do úvahy fungovanie kognitívnych procesov človeka a i blízkost' a ich relatívne úzku väzbu na používanie jazyka, ako i schopnost' niektorých teórii o jazyku byt' do vel'kej miery pravdivými v priereze dejín už od staroveku: Staroindická jazykoveda - Pánini, Staroveké Grécko - Platón, Aristoteles, Dionýz Trácky a d’alší, je odôvodnené to považovat' za dôkaz l'udskej schopnosti analytického nazerania na jazyk s možnost'ou pozitívneho potvrdenia schopnosti približovat' sa k objektívnej pravde o jazyku.

Vychádzajúc z uvedených argumentov, dostávame sa k otázke ako uvažovat' o jazykovej norme, jazykových normách? Je inšpiratívne pozorovat' odlišnosti v uvažovaní o jazykovej norme $\mathrm{v}$ jazykových spoločenstvách rôznych jazykov ako to podrobnejšie rozoberajú napríklad lingvisti Édith Bédardová a Jacques Maurals (1983). V súvislosti s vyššie spomenutými myšlienkami sme sa rozhodli rozdielnost' prístupov ilustrovat' na publikovaných názoroch vynikajúceho slovenského myslitel'a o jazyku Jána Kačalu. Na druhej strane syntézu frankofónnej lingvistickej tradície predstavuje jeden z jej najexceletnejších zástupcov gramatik Maurice Grevisse. Obaja sa zaujímali o vyriešenie otázky formulovania aktuálnej kultivovanej jazykovej normy a jej vymedzenia voči d’alším použitiam jazyka. Oboch ich spája najmä snaha o 
hl'adanie argumentov výstavby konkrétnych riešení kultivovanej jazykovej normy. Pozoruhodné je, že hoci obaja hl'adajú odôvodnenia, každý z nich odlišným spôsobom, hoci ciel' majú rovnaký. Preto sme sa rozhodli ich prístupy porovnat'. Je to zaujímave najmä z toho dôvodu, že obaja vychádzali s lingvistickej tradície ukotvenej v dejinách kodifikácie jazyka svojho jazykového spoločenstva. Maurice Grevisse zasadil do stáročnej tradície francúzskych názorov na kultivovanú normu pojem bon usage (v preklade dobrý úzus), ktorý bohato využíval a $\mathrm{v}$ súlade $\mathrm{s}$ frankofónnou tradíciou explikácie vzt’ahu normy a úzu, súc empaticky zacielený na používatel’ov jeho gramatického diela, ktorý ako sa neskôr ukázalo vel'mi pozitívne prijali jeho návrhy, hl'adá zdôvodnenie možnosti modifikovat' pravidlá. V súlade so zvyklost’ami pre francúzsky jazyk hl'adá oporu normy alebo dobrého úzu u prominentných používatel'ov jazyka, za ktorých boli vo francúzskom kontexte považovaní spisovatelia krásnej literatúry. Takto situáciu pre francúzštinu syntetizujú napríklad quebeckí autori Édith Bédardová a Jacques Maurals (1983) „v dejinách francúzskeho jazykového spoločenstva bolo klúčovým postavenie pojmu „bon usage“ vo francúzskom jazykovom povedomí, spolu s prepojením konceptu spoločenskej prestíže vo Francúzsku a vzorového jazykového správania, pričom jazyková kultúra bola v 20. storočí viazaná v prevažnej miere na Grevissov koncept a nie na chápanie Francúzskej akadémie." Preto vo francúzskych gramatikách, dlhé roky, pred nástupom lingvistiky elektronických korpusov, boli uvádzané príklady, ktoré boli citátmi z literárnych diel. Samozrejme takto dochádzalo k určitému oneskoreniu oproti aktuálnemu úzu, čo však napríklad predstavitelia Francúzskej akadémie vyslovene považovali za prínosné. Explicitne to vyjadril napríklad Maurice Druon (1992). V takom prípade dochádza k modifikácii normy až po ustálení neologizmu a nie predčasne, skôr ako sa vôbec zistí, či ide o trvácnejší jav. Maurice Grevisse však ponúkol i zaujímavé vysvetlenie ako pristupovat' $\mathrm{k}$ inovácii a čím podložit' prípadnú zmenu pravidiel pravopisu. Dôvodí tak, že je potrebné uplatnit' dávnu právnu zásadu, ktorej predchádza príklad „ked' sa dvadsat', pät'desiat, sto najlepších spisovatel'ov mýli rovnakým spôsobom alebo ked' jednotne v zhode používajú predtým zakázaný výraz, ani chvíl'u netreba pochybovat', majú pravdu. Práve v tomto sa doslovne napíña právnicky výraz communis error facit jus.“(Grevisse: 1961). V súvislosti s triadickým chápaním znaku tento jav Karel Sekvent (2011) popisuje z teoretického hl'adiska nasledovne: „Individuálna materiálna forma zvukov i grafických značiek vykazuje $\mathrm{v}$ rámci konvencie rozptyl limitovaný formami používanými pre ostatné označované a formami nekonvencionalizovaných označujúcich." Kde jasne definuje obmedzenia uvedenej situácie z pohl'adu jazykového systému. V kontexte slovenskej jazykovednej teórie sa problematike vzt'ahu normy a úzu podrobnejšie venoval Juraj Dolník vo svojom pomerne rozsiahlom diele Teória spisovného jazyka (so zretel'om na spisovnú slovenčinu) (Dolník: 2010). Na margo možnosti zmeny jazykového znaku píše Karel Sekvent (2011): „Individuálne odchýlky od konvencie na úrovni označujúceho i označovaného sa môžu konvencionalizovat' a stat' sa tak impulzom pre zmeny jazykových znakov.“ Otázka je, ako analyzovat' aplikovanie právneho princípu „communis error facit ius“ Mauriceom Grevissom vprípade zmeny jazykovej normy. Vzhl'adom na rozsah tejto štúdie sa zameriame $\mathrm{v}$ prvom rade na zvyklosti interpretácie tohto princípu v právnej oblasti, čo bude naším východiskom smerom $\mathrm{k}$ interpretácii jeho správnej aplikácie $\mathrm{v}$ lingvistike, ktorá je podl’a nášho názoru tiež možná, má však vážne dôsledky. Všeobecne sa v právnej spisbe prijíma a zdôrazňuje názor, že aplikovanie uvedeného právneho princípu predstavuje „nebezpečie, pretože zavádza nekoncepčnost' do fungovania právneho poriadku, narúša jeho princípy a likviduje ho tým, že zákon takým spôsobom uprednostňuje verejné dobro, že to umožňuje, aby sa rozšírený omyl stal právom.“ (Pease v. Peck: 1856). Napriek geografickej a časovej vzdialenosti vyberáme práve túto myšlienku, pretože právne systémy anglosaských krajín sú senzibilné na právny princíp precedensu v judikátoch, 
ktorý má potom spravidla dôsledky, citovaný úryvok je z rozsudku v prípade Pease $\mathrm{v}$. Peck, Najvyššieho súdu Spojených štátov amerických z roku 1856. Podl’a nášho názoru z oblasti práva je Grevissovmu postoju najbližšie klasické Rímske chápanie. „V starovekom Ríme to znamenalo, že všeobecne prijímaný názor, presvedčenie $\mathrm{v}$ právnej otázke vytvára z tohto názoru zákon.“ (2008), čo je identické s Grevissom. Rozdiel vzniká, ked’ si všimneme d’alšie explikácie k uplatňovaniu tohto právneho princípu, hlavne výhrady, že „všeobecne prijímaný názor môže byt' aj všeobecným omylom“ (2008) a tým, že v takýchto prípadoch „,do času kým sa na omyl príde, domnienka ostáva v platnosti““ (2008). Ide o to, že napríklad v prípade justičného omylu, by v prípade nemožnosti zvrátit' rozhodnutie súdu po zistení omylu, nemohlo byt' opravným rozhodnutím súdu zadost'učinené poškodenému a nespravodlivo odsúdenému, lebo by muselo communis eerror facit ius ostat' v platnosti, lebo v čase súdneho omylu panovalo všeobecné presvedčenie o jeho vine. Nie je preto t'ažké uviest' nadpočet príkladov, ktoré dokazujú, že naopak communis error non facit ius a pozitívna verzia je uplatnitel'ná len vo výnimočných situáciách. Ak to takto myslel a spojil Maurice Grevisse, neaplikoval to podl’a nášho názoru prevzatím z oblati práva na jazyk správne. Tvrdí totiž vo svojom vyjadrení viaceré kl'účové skutočnosti. Prvou je, že ešte predtým ako sa z omylu stane nové pravidlo je jasné, že ide o omyl. Ako sme práve ukázali v právnej perspektíve to mení už samotnú východiskovú situáciu a znemožňuje aplikáciu Grevissom proklamovaného pravidla. Berme však ako premisu, že ide o omyl len z pohl'adu kodifikovanej normy. Teda, ak by sme pripustili uplatnitel'nost' communis error facit ius v Grevissovom ponímaní, muselo by podla chápania právnikov nasledovat' prehodnocovanie podl'a prísnych kritérií dokazovania pravdivosti alebo nepravdivosti, teda či to, čo inovovali spisovatelia, prominentní používatelia jazyka, je vecne pravdivé alebo či bola pravdivá kodifikovaná norma. Konfrontácia $\mathrm{s}$ takouto vedomost’ou by $\mathrm{v}$ prípade zistenia pravdy podla právneho chápania navodzovala potrebu rektifikácie stavu navodeného uplatnením princípu communis error facit ius. Nepovažujeme za problém princíp inovácie jazykového systému úzom, považujeme za sporné také uplatňovanie tohto princípu, ktoré po rozšírení novinky už nepredpokladá skúmanie jej pravdivosti, napríklad len preto, že dôkazom je inovácia úzom dobrých autorov, akoby sa tí nemohli vecne mýlit'. Opak je však pravdou. Excelentne to dokazuje vo svojom diele Jazyk majstrov Ján Kačala (2014). Nejde totiž o mentorovanie autorom, ktorí sa vyznačili v dejinách literárnej kultúry jazykového spoločenstva, ide však o exemplifikáciu chýb, ktoré je možno argumentačne podložit' ako jazykovo nesystémové javy. Naviac, argumenty lingvistu sú takej povahy, že sú častokrát lucidné a plauzibilné i pre laickú verejnost'. A tu je podstata problému, Kačala svojim Jazykom majstrov (2014) poukazuje na skutočnost', že sú situácie, kedy je možné omyl dokázat' systémovo, napríklad v prípade homoným uvedením kompletnej paradigmy, kde sporným z hl'adiska snahy o prenos kodifikovanej normy do úzu je len jeden z jej tvarov. Potom by uplatnením error facit ius až do pravidiel nastala kuriózna situácia. Modifikáciou kodifikovanej normy novým úzom, napríklad literárnym by pri absencii korekcie a zistovania lingvistických argumentov vlastne takto zavedená kodifikácia mohla byt' používatel'mi neskôr l'ahko spochybnená, ked' by sa dozvedeli argument stojaci v opozícií proti nej a vzhl'adom na jeho systémovú logickost' by si ho osvojili. Preto sa prihovárame za rešpektovanie l'udskej schopnosti analýzy jazykových javov vzhl'adom na argumenty, ktoré súvisia s vnútorným ustrojením jazykového systému a jeho vzájomnou previazanost'ou a obojstrannou závislost'ou $\mathrm{s}$ rečou, ako psychofizyckou danost'ou.

Štúdia vznikla v rámci projektu KEGA č. 038UK-4/2014 Enunciatívny prístup v kontrastívnej gramatike - sloveso v románskych jazykoch a v slovenčine Enunciative approach in contrastive grammar - verb in Romance languages and in Slovak 


\section{Bibliographic references}

BEDARD, E. - MAURALS, J. 1983. La norme linguistique. Québec: Gouvernement du Québec 1983. ISBN 2-551-05243-2

DOLNIK, J. 2010. Teoria spisovneho jazyka (so zretelom na spisovnu slovencinu). Bratislava: Veda. ISBN 978-80-224-1119-6

DOLNIK, J. 2013. Vseobecna jazykoveda. Bratislava: Veda. ISBN 978-80-224-12018

DRUON, M. 1992. Dictionnaire de l'Académie française. Tome 1. Paris: Imprimerie nationale. ISBN 2-11-081249-4

GREVISSE, M. - GOSSE, A. 2011. Le Bon usage. De Boeck Supérieur. ISBN 9782-8011-1642-5

GREVISSE, M. 1961. Problèmes de langage, I. Paris: Presses universitaires de France.

HREBICEK, L. 2002. Vypraveni o lingvistickych experimentech s textem. Praha:Academia. ISBN 80-200-0973-6

KACALA, J. 2014. Jazyk majstrov. Bratislava: Spolok slovenskych spisovatelov. ISBN 978-80-89727-12-4

Langue-fr.net. [Online] <http://www.langue-fr.net>

Pease v. Peck, 59 US 595 - Supreme Court 1856, [Online] https://scholar.google.ca/scholar_case $?$ case $=14359525909402132209 \& q=59+$ U.S. +59 $5 \& \mathrm{hl}=$ en\&as $\mathrm{sdt}=2006$

ONDRUS, S. - SABOL, J. 1984 : Uvod do studia jazyka. Bratislava: SPN.

SAUSSURE, F. 2007: Kurs obecne lingvistiky. Praha: Academia. ISBN 978-80-2001568-6

SEKVENT, K. 2011. Triadicky znak. In Jazykovedny Casopis, vol. 62, n. 1, pp. 4150.

ISSN 00215597 doi:10.2478/v10113-011-0003-9

West's Encyclopedia of American Law, edition 2. 2008 The Gale Group, Inc. ISBN 978-0787663674

Words: 2370

Characters: 17278 (9,59 standard pages)

PhDr. Mojmir Malovecky, PhD.

Department of Romance Languages and Literatures

Faculty of Education

Comenius University in Bratislava

Račianska 5, 81334 Bratislava

Slovakia

malovecky@fedu.uniba.sk 